\title{
Market mechanisms' distortions of higher education: Punjabi international students in Canada
}

\author{
Lilach Marom ${ }^{1}$ (D) \\ Accepted: 31 January 2022 / Published online: 17 February 2022 \\ (c) The Author(s), under exclusive licence to Springer Nature B.V. 2022
}

\begin{abstract}
This study explores the experiences of Punjabi (i.e., from the Punjab region in India) international undergraduate students (hereafter PS) attending Canadian higher education through a case study of a teaching university in British Columbia. The primary focus is on unpacking how PS' experiences were underlined by labor mobility, immigration policies, and the marketization of international higher education. To recruit international students, many lower-tier Canadian universities apply a business model that relies heavily on agents. The outcome is that educational considerations are not central to admission and retention processes. The findings critique the Canadian education-migration model by identifying the complicity of Canadian higher education in lower-skill immigration and the negative educational and professional outcomes for PS that result from this complicity. The study highlights PS' voices and experiences that can go overlooked in the context of market-driven higher education.
\end{abstract}

Keywords Punjabi international students - International higher education · Marketization · Education agents $\cdot$ Education-migration

\section{Introduction}

This case study explores international undergraduate Punjabi students' (i.e., from the Punjab region in India; hereafter PS) experiences at Kwantlen Polytechnic University (hereafter KPU), a mid-size Canadian teaching university. My main research interest was unpacking PS experiences as underpinned by labor mobility, immigration policies, and the marketization of international higher education (hereafter $\mathrm{HE}$ ).

Between 2010 and 2019, Canada saw a 185\% increase in international students (hereafter IS) (Canadian Bureau for International Education [CBIE], 2020), with 60\% planning to apply for permanent residency (PR) (CBIE, 2020). Since 2015, the proportion of IS from India has grown considerably, with $67 \%$ growth at the college level (CBIE, 2018). Prior to COVID-19, "In colleges, India was the top source of international enrollment in most broad program areas" (Frenette et al., 2020, para. 8).

Lilach Marom

Lilach.marom@kpu.ca

1 Kwantlen Polytechnic University, Surrey, BC, Canada 
Key factors underlying this growth include the expedited visa procedures for IS from India under the Student Direct Stream (SDS), which provides student visas within 20 calendar days (Government of Canada, 2019a), expansion of the global HE market, Canada's relatively easy route to immigration post-graduation, and the political climate in other countries. England, for example, historically desirable to Indian IS, changed student visa requirements to prevent automatic extension to a work visa post-graduation; this led to a steep decrease in Indian IS (Beech, 2018). Additionally, in Australia, an increase in racist incidents toward Indian students made that destination less inviting (Baas, 2010).

In the complex context of neoliberal global HE, IS are often seen as "money makers" by Canadian universities (Todd, 2019). In the last decade, Canada's 147 public universities have increasingly relied on international students, "who pay substantially higher tuition than domestic students," as a revenue source (Statistics Canada, 2020, para. 6). To recruit international students, many Canadian universities rely on agents. The term "education agent" refers to an individual or organization offering "education advising services to students... in exchange for a fee... and/or a commission" (Coffey \& Perry, 2013, p. 6). Agents facilitate the recruitment process from advertisement to admission, including English testing, document procurement, and visa procedures (Collins, 2012). Agents have become integral to international $\mathrm{HE}$, "with both universities and students viewing agents as gatekeepers to international students and higher education opportunities, respectively" (Beech, 2018, p. 611). India has the most agents (30\%) used in Canadian HE (Coffe \& Perry, 2013), many located in "untapped markets" such as Punjab.

While there are studies on Indian IS in Western universities (Baas, 2010; Caluya et al., 2011; Houshmand et al., 2014), PS as a distinct (yet not homogenous) sub-category of Indian IS are under studied (Marom, 2021). Many PS come from social strata that until recently did not attend HE (Government of Punjab, 2020; Kahlon, 2021). The Punjab region, although only $1.5 \%$ of India's geographic area, grows $1 / 4-1 / 3$ of India's essential crops: Punjab's agriculture is "a driving force in the state" (Government of Punjab, 2020, p. 5). However, the instability of the agriculture sector contributes to increased diasporic tendencies among young Punjabis from farming families, who are "migrating abroad in search of employment opportunities" (Government of Punjab, 2020, p. 25). Other key push-pull factors (Mazzarol \& Geoffrey, 2002) triggering PS' international aspirations include high unemployment rates among the educated and skilled workforce in Punjab and limited avenues for youth to move from farming to non-farming jobs. Recent surveys of Punjab highlight that "more and more farmers (especially small and marginal farmers) have been selling their lands to fund the migration of their children abroad" (Government of Punjab, 2020 , p. 25). Punjab's drug crisis is another factor contributing to the large efflux of PS to Canada. The Chief Minister of Punjab claimed that "If Punjab is made a drug-free state, then there will be no need for parents to send their children abroad" (cited in the Hindustan Times, 2018, para. 3). An article in The Hindu agreed that

The two serious issues of drugs and mass emigration are not unrelated. The drug menace in the state is a grim reality, especially in rural areas. Parents, worried about losing their young sons to drugs, are left with no choice but to send them away. (Mehra, 2019, para. 4)

Socio-economic problems and the hope for a better life drive many PS to seek education-migration - the process of recruitment and retention that morphs IS into immigrants. Like other IS on the education-migration nexus (Robertson, 2013), PS often find themselves subjected to deficit terminology at host universities, constructed as students of 
"lesser quality," and as merely aspiring immigrants rather than "real students" (Baas, 2010; Birrell, 2005; Caluya et al., 2011; Sidhu, 2005, 2006).

Drawing on Sheller's $(2018,2019)$ frame of mobility justice that highlights issues of power and inequality underlying the governance and control of movement, I explore the mobility of PS from a rural periphery in the Global South to the Global North through the funnel of HE. This study demonstrates injustices in the education-migration nexus on multiple levels (Brunner, 2022 in press). On the individual scale, it explores PS experiences at a lower-tier Canadian university. On the institutional scale, it demonstrates the complicity of Canadian HE in market-driven recruitment and admission processes. On the national scale, it examines $\mathrm{HE}$ as a component of the Canadian labor migration industry (Haynes, 2017; Trilokekar \& El Masri, 2019). Finally, on the global scale, this study reveals the uneven distribution of power in the global arena that drives PS from underprivileged backgrounds to seek mobility through Western education, often at a high personal and professional price (Stein \& Andreotti, 2016).

\section{Education-migration and the internationalization of $\mathrm{HE}$}

Labor mobility from the Global South to the Global North is rooted in the history of colonialism and slavery and entangled in the principles of capitalism and neoliberalism (Haynes, 2017). Where world leaders no longer openly condone the forced movement of people, subtler forms of exploitative mobility have emerged. Education-migration, under the umbrella of the internationalization of $\mathrm{HE}$, is one such example.

While internationalization has academic, social, political, and economic agendas (de Wit, 2002; Harman, 2004; Knight, 2003), the neoliberal shift of the 1970s toward a global knowledge economy plays a key role (Weis \& Dolby, 2011, 2012). Grubb and Lazerson (2009) call this shift the "educational gospel"- the belief that education drives economic development and establishes the foundation for knowledge-based economies with large populations of skilled workers. The neoliberal shift in education shrunk government funding and constructed global universities as competitors, with an eye to increase revenues through expansion into international markets (Harvey, 2005; Olssen \& Peters, 2005). This agenda signalled another shift, "from aid to trade" (Harman, 2004): from providing education to students in developing countries as a public good to recruiting IS as a revenue stream (Connell, 2013; Mazzarol \& Soutar, 2001, 2002).

International education has become a profitable export industry for many Western countries (Naidoo, 2010; Zheng, 2014), increasingly constructed as an easy route to migration (Cranston et al., 2018). Undergraduate IS who pay full tuition, in particular, have become the target of "a global migration industry in higher education" (Beech, 2018, p. 611), resulting in many IS gaining access to lower-tier universities and programs (Altbach et al., 2010; Marginson, 2004; Thomas \& Bell, 2008). However, the prospects of these students in the global economy have not necessarily improved (Gamoran, 2008). In fact, critics argue that the internationalization of education has led to growing global inequity (Brown \& Lauder, 2006; Brown et al., 2011), where IS function as the "products" of educationmigration (Robertson, 2013), earning low-tier university credentials that put them on the path to low-skilled job migration (Haynes, 2017).

This is the case in Canada. The last two decades has seen a decline in Canada's population growth and its educated labor force (World Bank, 2021), leading it to look to educated immigrants as a source of both population and economic growth. Historically opposed to 
the conflation of education and immigration, Canada has come to embrace it (Immigration, Refugees and Citizenship Canada [IRCC] 2020, 2021). This is indicated in the creation of the 2015 "express entry" PR category, which "manages applications for permanent residence from skilled workers" (Government of Canada, 2020), and which replaced the "first come first served" system. Constructed initially as a pool of temporary foreign workers (TFWs), IS have evolved to represent "ideal immigrants," while Canada's IS policies have become "synonymous with immigration policy" (Trilokekar \& El Masri, 2019, p. 47).

Income generation is another key goal of internationalization in HE (Knight, 2003). In 2018 , IS "spent an estimated $\$ 21.6$ billion on tuition, accommodation and other expenses" (Government of Canada, 2019b, p. 2). With public funding on the decline, Canadian universities have been pushed to generate revenue (CUPE, 2018). Recruiting IS, seen as "cash cows" that pay higher tuition fees (Scott et al., 2015), is an easy way to achieve this. In $2020 / 21$, international undergraduates paid on average close to five times the annual tuition of the average domestic student $(\$ 32,041$ vs. $\$ 6,610)$, which "accounted for almost $\$ 4$ billion in annual revenue for Canadian universities in 2017/2018" (Statistics Canada, 2020, para. 7). The CBIE cautions, "financial imperatives must not dictate the internationalization agenda" (CBIE, 2014, p. 2), yet many universities, KPU included, are increasingly dependent on international tuition fees and, thus, are active participants in the educationmigration pipeline.

\section{Methodology and data sources}

KPU is a mid-size polytechnic university located in BC that serves approximately 20,000 students annually. It is the only polytechnic university in BC, as captured in its tagline, "where thought meets action." KPU is an "open access" university, which means that admission is based on English proficiency and a high school diploma. The influx of IS challenges KPU's open access policy because of the incompatibility of report cards from non-Western school systems with Canadian ones. As a result, with IS admission, the greatest weight rests on English exams such as the IELTS. Punjabi native speakers' scores sit near the bottom of the IELTS ranking (IELTS, 2019).

As of fall 2017, KPU has seen a dramatic increase of $174 \%$ in international student enrollment, mainly from India (Shan et al., 2019, p. 2). In the 2019 fall term, 25\% of KPU's student body was composed of IS (from 11\% in 2015). Fifty-eight percent of IS self-identify as first generation to attend university, and 96\% self-identify as "visible minorities" (KPU, 2017). The most prominent country of origin for IS at KPU is India (80\%), followed by China (13\%). While Punjabi Sikh are a minority in India (less than $2 \%$ according to the 2011 census), they constitute the majority of IS at KPU at 60\% (KPU, 2020b).

KPU is particularly appealing to PS because of its low tuition fees relative to other universities. It is also the only teaching university with a main campus in Surrey, home to the largest Punjabi community in BC (Statistics Canada, 2016), where PS can easily access ethnic food and places of worship. KPU's popularity has increased through social networking as PS recommend the university to friends and relatives back home (Beech, 2015; Marom, 2021).

This project was designed as a case study focusing on the experiences of PS at KPU (Hamel, 1992; Yin, 2009). The main source of data was qualitative, semi-structured interviews (Kvale, 1996; Seidman, 2005). I used purposive sampling (Etikan et al., 2016), targeting KPU students who identified as PS. Recruitment advertisements were posted at 
KPU, and information was sent to students in all faculties. I conducted 16 interviews with PS that were focused on topics such as enrollment processes, experiences and challenges at KPU, and personal and work experiences off campus.

The PS participants were between the ages of 19 and 21 and had arrived in Canada within the last three years. All but two were Sikh (practicing to different degrees), and all were first generation to attend university in Canada. Most PS came from a farming background and grew up in villages or small towns. All participants worked while studying and were financially supported (to various degrees) by their families in India (see Table 1 for PS details).

I also interviewed two faculty members with extensive experience teaching international students and five administrators in roles related to international education and IS. My goal in these interviews was to unpack the wider institutional mechanisms framing PS experiences. To protect their anonymity, I use pseudonyms for PS and titles for faculty and administrators.

Beyond the interviews, I examined provincial and federal policies regarding HE, labor, and immigration, as well as KPU's strategic plans, policies, and senate documents related to IS. In addition, I compared my data with data from qualitative surveys of IS undertaken by KPU (2017) and the World Sikh Organization in Canada (Baughan \& Minhas, 2018). These sources were juxtaposed with PS experiences and used as a form of triangulation.

\section{Findings}

\section{Agents as gatekeepers to higher education}

Facing continuous budget cuts, Canadian universities and colleges saw the eligibility of Indian students for the Student Direct Stream (SDS) visa as an opportunity to increase revenues. In an interview in The Runner, KPU's student newsletter, the former provost acknowledged, "[it] has turned into an aggressive market" (cited in Keller, 2018, para. 8). KPU facilitated a sharp increase in PS admission, often at the expense of the quality of service these students received. An administrator shared,

We were given a target: "You need to double our international students in 12 months." All we worked on was to expand and expand and recruit more students. But we are reaching the point right now to say, "Okay, we have enough agents. We really need to control the quality of them," because more and more, students showed up here in Canada and got so lost. They're in the wrong classes, they got the wrong information, they paid the wrong amount of money.

Lower-tier universities, unlike "super-league" institutions (Marginson, 2009, 2016), rely on recruitment agents to boost their global reputation (Coffey \& Perry, 2013). KPU currently works with approximately 50 agents, many of whom operate in the Punjab area. Manpreet explained that "in Punjab, there are so many agents. Within 2-3 kms you can find every different agent." Similarly, Punjab has an estimated 5000+IELTS centers, the vast majority unregulated (Roy, 2019). The desire to come to Canada is so great that pop culture references IELTS and agents (Kahlon, 2021).

PS heavily rely on agents in the admission process; all the PS in this study used such services. Pravinder shared her rationale: "I don't have much knowledge about...the whole process, and it was my first time. No one in my family has done this... So, instead of taking risks, I went to an agent." Gagandeep felt similarly reassured by agents' expertise: 


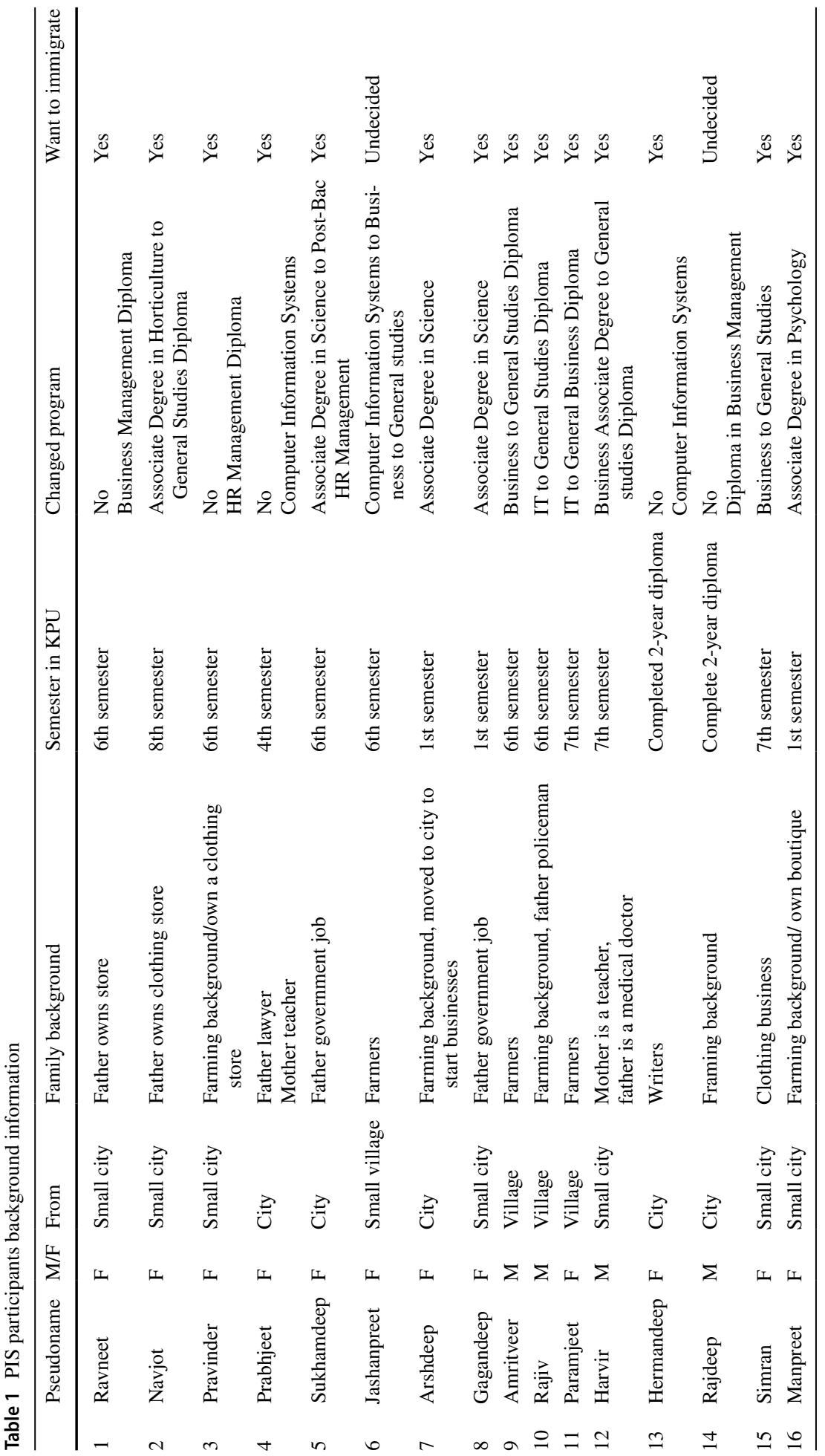


I used an agent because I have heard about some people who did their process on their own, and...the applications got rejected because they missed something... Back in India, it's considered best if you hire an agent so he could do good work for you.

In some non-Western cultures, there is a preference for mediation in important decision-making processes (Bodycott \& Lai, 2012). Furthermore, IS from less-affluent backgrounds often require agents to navigate unfamiliar terrain (Pimpa, 2003) and help them "choose a country, institution, credentials, and course of study from a range of mostly unfamiliar options" (Coffey \& Perry, 2013, p. 2). Most PS have limited knowledge of the options for international $\mathrm{HE}$ and assume all foreign institutions are quality ones, a belief that makes PS easy to manipulate (Kaur \& Singh, 2018).

PS families willingly spend vast sums of money on agent services since studying abroad is seen as a means to advance their children's future (Government of Punjab, 2020); however, information asymmetry underlies the admission process. An administrator explained:

It turns out that a lot of agents, they're faking students' personal emails. They actually create an email and tell us that it's the students' email. So, when we send all these communications to students, we thought the students got it, but students would show up and say, "I never received the information. I didn't know the timeline. This is the wrong course..." Some agents, they create an email account that looks so similar to a personal email account. How would you know it's not from the students?

Asymmetry in information can lead to cases of fraudulence (Tuxen \& Robertson, 2018; $\mathrm{Xu}, 2020)$, as in the case above, where agents interrupted email correspondence between KPU and PS. Such interruptions can negatively impact relationship building between institutions and prospective students (Gomes \& Murphy, 2003).

Since PS consider hiring an agent the safest route to international universities, agents have considerable power as gatekeepers of the admission process, which they can abuse. While agents can act as "cultural mediators," bridging the gap between home and host countries (Robinson-Pant \& Magyar, 2018), educational considerations do not necessarily play a central role in student recruitment (Baas, 2010; Caluya et al., 2011). Many PS shared how, in hindsight, agents did not always serve their best interests. Rajiv reflected,

When I think back, it was, for them, a business, so they didn't give me honest advice...I actually trusted them blindly, but that was wrong... because these agents, maybe they have some links with KPU... Probably KPU pays them to "give us this many students."

Indeed, agents have significant control over which universities and programs PS learn about. Offerings are often motivated by business considerations, as reflected in many PS stories, where they were only introduced to universities and colleges from the second tier or below. Prabhjeet shared,

No one was familiar with the process to get into UBC and SFU [research universities in $\mathrm{BC}$. I researched everything about UBC, and I came to know it's one of the top universities in Canada. I was like, "I really want to go to that university" ... But...I felt that nobody could help me with the application process. So, I had to drop that.

Similarly, when Rajdeep inquired about UBC, his agent claimed a transfer between institutions would be simple. However, as he shared, "once I contacted UBC after a semester at KPU, they said...they do not accept transfer students... So, I think that the agents were just doing it for their money, like they don't really care where you go."

While higher-tier universities did not even appear on agents' lists, when it came to similarly ranked options, the selection process seemed market driven. Gagandeep shared,

The [agents] said, "Oh, we have one spot left at KPU, so if you want that, we can grab that for you." So, I was really lucky to get this opportunity, I guess... because it depends 
more on the agent... They're always like, "We don't have seats for this, but we have another seat. If you want to take the seat, you have to go for this process now."

Studies identify some benefits of using agents in a regulated and supervised environment (Collins, 2012; Thieme, 2017). Universities benefit from the agents' local market understanding and their geographic, linguistic, and cultural knowledge while students and families benefit from support in the application process and beyond (Dunstan, 2009; Robinson-Pant \& Magyer, 2018; Tian, 2017). However, as indicated above, numerous problems arise when agents work in an unregulated, competitive global context. Problems include a lack of transparency, conflicts of interests, "double dipping" for fees, and cases of fraudulence (Collins, 2012; Raimo et al., 2014; Tuxen \& Robertson, 2018). While agents often base academic offerings on business considerations, their advice can have long-lasting impacts on PS' academic trajectories.

\section{The problem with institutional dependence on agents}

Many PS received incorrect or misleading information about registration and course selection. When they arrived at KPU, it was often too late to change their courses, which placed them at an immediate academic disadvantage. Paramjit shared, "at the international orientation day there was a rush of international students...trying to talk to an advisor, but after the deadline, it's not worth anything." Many PS discovered last minute that agents had enrolled them in courses without their knowledge. Part of the confusion emerged because, within the Indian education system, students enrolled in academic streams (e.g., science, commerce, art) are automatically assigned a fixed set of courses. Thus, PS had no reason for concern when they were left out of KPU's registration process. PS also had no way of anticipating a mismatch between program prerequisites in India and Canada.

In some cases, registration in the wrong courses had severe implications for PS' academic trajectories. Since IS tuition at KPU is three times higher than domestic student tuition, every extra course PS require due to misinformation has significant financial implications. Sukhamdeep shared, "I was misguided with [my choice of program]. When I came to KPU, the advisors told me, 'Yes, we can shift your program,' but I already wasted my first semester. I wasted \$7,000 directly when I came to KPU.” A KPU instructor offered an example of the consequences of agents' registering on PS' behalf:

A [PS] told me that she wanted to take sciences. That was her dream. The agent told her, "No problem. You'll get into sciences." But when she came here, she realized she didn't have the math equivalency ... She was never told that ... They come here and realize they must pay more to get the required course.

KPU's international office is aware of the crucial role agents play in PS' academic success. As an administrator shared,

Whether it's an agent not being fully trained about KPU's programs or our requirements, or they just simply don't follow it because of their own kind of purposes-I honestly don't really know where each of the agents is coming from. One thing that I know is that the courses the agent helps the students register for in their first semester are crucial for the student's continued education in a Canadian institution.

The international office aims to mitigate problems by vetting agents, providing better agent training, and circulating clear information. KPU offers time-limited contracts to agents, which they extend based on positive performance or terminate based on a record of recurring issues (students can also use "independent agents," who are not contracted by an institution (Xu, 2020)). KPU's international office also works to establish advance 
communication channels with IS to ensure students are correctly informed. As an administrator shared, "the purpose of it is...to have an opportunity to create a communication channel on a more one-on-one kind of a format without the agent being involved."

While institutional changes are a step in the right direction, they cannot eliminate all problems that emerge from KPU's dependence on agents. Providing effective supervision across linguistic, cultural, and geographical boundaries is complex (Coffey \& Perry, 2013) and has become even more so with the emergence of "aggregator recruiters"-companies that take the role of middlemen between institutions and students, hiring and supervising agents en masse. A key player in the Canadian arena is ApplyBoard which, under the tagline, "Help us educate the world! We believe that education is a right, not a privilege" (ApplyBoard, 2021, para. 1), offers universities competitive rates coupled with less accountability. While the problems embedded in the agent model are striking, KPU, like other institutions whose enrollment depends on agents, "may be reluctant to confront agent misconduct for fear of having them refer students elsewhere" (Coffey \& Perry, 2013, p. 2).

The notion of agents being, in the words of an administrator, "not really [KPU's] representatives - but you know, sort of arms-length representatives in different countries" distorts the academic process. Although the agent model ostensibly maintains a non-selective admission process that fits KPU's profile as an open access institution, it has a detrimental impact on PS retention and career advancement.

\section{International students as "cash cows"}

The BC provincial government regulates domestic student tuition, ensuring an increase of no more than $2 \%$ per academic year. International tuition, meanwhile, is unregulated. As a result, IS are exposed to unpredictable fluctuations in their tuition fees. An administrator explained, "There is no law that restricts us to increase international tuition by any specific percentage. So, there's nothing stopping universities from increasing [it].” Indeed, in 2018, KPU, whose lower tuition was a key part of its appeal for many PS, increased international tuition by $15 \%$ (spread over two years). As a basis for the increase, the senate endorsement statement presented a table comparing KPU's international tuition to other universities (KPU, 2018, p. 74). Another rationale behind the increase was IS' need for more institutional services and support. KPU's former provost told The Runner (Laube, 2018) that "paying for services such as academic advising, the multi-faith center, and peer tutoring...puts financial pressure on the university... in particular staffing the learning center and the KPU international office, as well as compensating recruiters and agents abroad" (para. 24). Notes from the board of governors meeting (KPU, 2018) state that "while yearover-year international revenues have increased by approximately $70 \%$, agent commission fees have increased by over $220 \%$. These fees... are now more than we spend on the international division itself" (p. 73). While KPU has seen a significant increase in revenues from international student tuition, considerable funds go toward maintaining its marketing mechanisms.

For many PS, the sudden increase in tuition had a devastating impact. Changes in immigration laws that made it easier for students to gain a post-graduate work permit (PGWP), a sub-category of TFW that, under certain conditions, can lead to PR, changed the makeup of the IS body (Beech, 2015, 2018). Many PS from non-affluent backgrounds apply to Canadian universities with the hope of a better life trajectory for themselves and their families, and parents often invest significant resources to send their children to study abroad (Baas, 2010; Brooks \& Waters, 2011). An administrator explained, 
A lot of people...they don't really have the money. They have either taken loans, or they have sold property there. So, the expectations on a child coming here are very, very high. It's like, "Hey, we're selling our property. We're selling our land. We're sending you abroad to study. Make sure you do well."

PS' awareness of their families' sacrifices increases the pressure they feel. Ravneet shared, "families put all their savings into this process, so that becomes a kind of pressure, a mental pressure, on the child, that he has to settle here on his own." Pressure increases, too, if PS perform poorly academically. As Simran explained, "When I failed the courses, I wasn't able to talk to my parents about that...I had to move to my friend's house to pay the fees."

PS have limited economic support from their families; most need to work to support themselves. The economic pressures impact PS engagement and academic success. An instructor shared, "It's a typical story for PS where they would pull graveyard shifts and then go into my morning class." Since student visas limit IS to a maximum of $20 \mathrm{~h}$ of work a week (Government of Canada, 2019c), many PS opt to work illegally, which can lead to work-based exploitation (Baughan \& Minhas, 2018; Hune-Brown, 2021; Marom, 2021).

Wadhwa (2016) differentiates between Indian IS motivated by education/career advancement (those focused on institutional reputation, specific programs, etc.) and those seeking immigration. The PS in this study belong to the second category as they apply to lower-tier universities and non-prestigious programs. Yet this typology must be contextualized within the limited options for mobility available to PS based on their socio-economic status, ethnicity, and the specific circumstances of the Punjab region. Enrolling in a lowertier university with high market dependency, PS education-migration was underlined by education distortions, starting with admission, continuing with program and course selection, and intensifying with unexpected tuition hikes. PS found themselves in a vulnerable position where their educational trajectory had landed them in an "opportunity trap" (Brown et al., 2011, p. 133). With much at stake, PS still had to secure a route to migration.

\section{University as a route to low-skilled jobs}

Canada has recently put regulations in place to limit international recruiters' ability to exploit low-skilled workers (e.g., for agriculture and elderly care) from developing countries (Agunias, 2013; Barrientos, 2013; Tomlinson, 2019). This has had a ripple effect on education-migration, with "study permits... [becoming] the new hot seller for recruiters, who can then steer the students to low-skilled jobs with their employer clients" (Tomlinson, 2019, para. 23). Since the 2016 inclusion of India in the SDS, study permits have become popular with PS as a pathway to Canada. This phenomenon adds to the image of PS as immigration seekers rather than "real students" (Baas, 2010; Caluya et al., 2011).

The intertwined nature of education and migration shows itself in PS enrollment patterns. While $77 \%$ of domestic students study toward an undergraduate degree, the majority of PS (52\%) enroll in two-year diploma programs (KPU, 2020b). Many PS indicated that they could not afford four years of international tuition. Academic challenges coupled with tuition hikes drove others to downgrade their program of study to a less demanding one. Seven of the participants changed their program of study from a specialized one (e.g., business or IT) to General Studies. In the graduation roll for the 2019/2020 class, the overwhelming majority listed under "Diploma in General Studies" are PS (KPU, 2020a). An administrator explained this phenomenon: 
It's an easy way out...that's what they care about. For General Studies, they can take random classes, and they will graduate, which will allow them to get a work permit so they can work after graduation. Some say that they will come back once they have immigrated, as domestic students, because the difference in tuition is quite substantial. But we never know. A lot of them just graduate with General Studies and never come back.

While many PS explained their decision to switch programs in terms of time and monetary constraints, their stories did not carry the deficit overtone of the comment above. Many interviewees indicated that they did not apply to KPU with the intention to take a general program, but resorted to this option due to their inability to overcome the multiple challenges they encountered along the way. PS named a few reasons for switching to General Studies, such as the higher cost of specialized courses (e.g., advanced four-credit courses and labs), waitlists for mandatory courses in specific programs, and the fear of failing courses which, in addition to having an economic impact, could lead to academic probation or expulsion. Internal data reveals that in the 2018/2019 academic year, 21\% of KPU's IS were on academic probation (in comparison to $5 \%$ of domestic students). As Harvir shared,

[In General Studies] I was sure about the courses that I could pass. If I fail a course, I will have to pay that $4 \times$ more again, and I would be at a big risk to proceed in this country... If I don't get good grades, I won't even be able to start my life here. It will end before it even starts, right?

Some PS who sought academic advising received generic advice on the easiest courses for an expeditious graduation. Sukhamdeep shared, "It's like the academic advisors only feel that we are here to get PRs, so they just tell us which way we won't face difficulties in getting PR or a work permit in the future. But they don't think we even have to complete our studies." Similarly, in a study on IS at lower-tier universities in immigrant-dependent countries, Tran and Thao (2016) argued that administrators' and faculty's perception of students as mere "migration hunters" impacted the academic support they received.

While the Canadian immigration model is globally praised for matching its labor market needs with migration trends (OECD, 2019), education-migration is questionable in terms of IS' job prospects (Choi et al., 2021). A report by Citizenship and Immigration Canada (CIC) (2015) states that, "While some find skilled work, data indicates that a large proportion of PGWP holders are working in low-skill/low-wage jobs" (p. 9) (in 2019, 54.5\% of PGWP holders originated from India). Furthermore, Chen and Skuterud (2021) argue that IS transitioning to PR "experience disparities in labor market outcomes relative to their domestic counterparts graduating from similar academic programs" (p. 126); disparities can persist "for as long as 20 years" (p. 126) and are evident in earnings, employment rates, and the mismatch between education levels and jobs.

My study similarly suggests that the academic trajectory of PS at lower-tier universities leads to low-skilled jobs (IRCC, 2018). PS credentials and limited work experience hardly put them in a position to "win" in Canada's competitive "express entry" PR category, where they share the applicant pool with $\mathrm{PhD}$ graduates and internationally educated professionals (Hou et al., 2020). Hence, despite investing considerable money and effort, PS often graduate with a diploma that leads to a limited career trajectory. An alternative route to PR is through TFW status, particularly via jobs that qualify for the Labour Market Impact Assessment (LMIA). LMIA justifies hiring foreign workers where no Canadian candidates can be found, often for labor-intensive jobs or jobs in remote locations. LMIA policy leads to fraud by "ghost consultants" who charge thousands of dollars for LMIA, and by employers who provide IS with LMIA in return for cheap or free labor (Dahmi, 2021; Kahlon, 2021). The BC government has created a system of reporting LMIA fraud 
(BC Government, 2021); arguably, this system is "too little too late" to negate the exploitative construction of education-migration, particularly for students in lower-tier universities and generalized programs.

\section{Discussion}

This study identifies the injustice in education-migration on multiple interconnected levels through an examination of "who and what can move (or stay put), when, where, how, under what conditions, and with what meanings" (Sheller, 2018, p. 2). On the individual scale, PS gain access to Canadian HE but not to universities or accreditation that leads to professional careers in Canada. Many PS indicated that immigration to Canada was one of their goals in studying abroad, yet they also chose KPU because it was a "reputable institution." Misinformation and missing information in the recruitment process coupled with the limited opportunities they had in Punjab pushed PS abroad, often without full understanding of the rough journey ahead.

On the institutional scale, agent manipulations during the admission process and market-driven, unregulated tuition fees have long-term repercussions on PS's education trajectory, yet universities assume little to no responsibility for the future success of these graduates. Thus, KPU can be seen as one of many "PR factories" worldwide (Birrell, 2005; Sidhu, 2005, 2006), institutions that target students for whom "PR is just as (or even more) important than the quality of education received in the end" (Baas, 2010, p. 2). When the admission of potential students is mitigated by agents who earn money per-capita, and when program choice and course registration are guided by market variables rather than educational considerations, KPU no longer operates as an open access polytechnic university. KPU's tagline "where thought meets action" becomes ironic as many PS find themselves in programs that lead to low-skilled jobs (Choi et al., 2021).

On the national scale, this study demonstrates the complicity of Canadian HE with the migration industry. While education-migration in Canada rests upon the assumption that an international education provides a route to both immigration and valuable credentials for skilled work (Brunner, 2022 in press), in reality, the PS trajectory skews toward immigration, often at a high personal and professional cost (Kahlon, 2021). Lastly, on the global scale, this study demonstrates how power imbalances between the Global South and the Global North, along with the assumed superiority of a Western education, fuel educationmigration (Stein \& Andreotti, 2016). Escaping poverty and hardships in their home country, PS often find themselves trapped in an exploitative system in another (Kahlon, 2021). When HE becomes a pipeline for racialized IS to take on low-skilled jobs post-graduation, it (re)produces a societal order underpinned by racial and economic hierarchies.

\section{Concluding thoughts}

This study demonstrates how the entanglement of Canadian HE with marketization and immigration policies impacts both the quality of education and the job prospects of PS (Choi et al., 2021). While PS work to advance their limited "mobility capital" (Kaufmann et al., 2004) they become targets for lower-tier Canadian universities whose dependency on agents and international tuition makes them complicit in the commodification of HE. $\mathrm{HE}$ of this kind particularly harms IS from less-affluent backgrounds who require careful 
guidance. I argue that institutions that admit IS have a responsibility to provide them with the conditions and support that allow them to succeed rather than turn HE into yet another route to low-skilled migration (Beech, 2018; Choi et al., 2021).

Several recommendations emerged from the data. On the policy level, unregulated international tuition fees open the door to competition between universities and put PS in a vulnerable position; hence, tuition regulation is needed to protect IS. Work restrictions under the student visa should also be reconsidered. The rationale behind limiting work hours is that students more fully engage in schoolwork, yet the restriction can push students toward low-skilled and illegal work. Similarly, the criteria for the PGWP must be revisited as it currently motivates institutions to offer low-quality educational programs (CIC, 2015). There should also be increased transparency regarding immigration routes, and increased enforcement against exploitative hiring and "ghost consulting." While it is naïve to assume that universities will stop using agents, developing robust and compulsory governmental and provincial regulations could keep universities accountable and protect students (Coffey and Perry, 2013). Agent recruitment and training require close supervision, and alignment between agents' recommendations and academic considerations should be foundational to any collaboration.

At the university level, while open access HE is a noble idea, it must align with admission requirements and a support system that allows IS to succeed academically. IELTS results are not a sufficient indication of academic readiness (Bascaramurty et al., 2021; Keung, 2018). Student services play an important role in supporting IS and should be offered on a consistent, holistic, and personal basis. This support could help detect signs of problems before they lead to academic probation or a change of academic program. Services offered by staff of similar ethnicity and in IS' first language would also improve access (Kahlon, 2021).

PS chose to study in Canada with the hope of a better educational and professional trajectory. Prabhjeet shared,

I want to study, and I want to do something with my life, and I think education is the only way I can do it. If I'm not getting a good education back in my hometown, obviously I would like to go to some place where I can get a good education.

This study urges Canadian universities to take Prabhjeet and her peers' hopes for quality education seriously.

Funding My gratitude to Kwantlen Polytechnic University for supporting this study. A heartfelt thank you to Maren Elfert, Lisa Brunner, and Gurkirat Singh for their feedback, suggestions, and advise, and to Hanako Masutani for careful reading and editing. My deep gratitude to HIGH reviewers for their constructive critiques that significantly improved the quality of this paper.

The author received KPU a PD20-63 Fund for this study.

\section{Declarations}

Conflict of interest The author declares no competing interests.

\section{References}

Agunias, D. R. (2013). What we know about regulating the recruitment of migrant Workers. Migration Policy Institute, 6, 1-13. https://domide.colmex.mx/Archivos/Doc_6024.pdf 
Altbach, P. G., Reisberg, L., \& Rumbley, L. E. (2010). Trends in global higher education: Tracking an academic revolution. Sense Publishers in conjunction with UNESCO.

Applyboard. (n.d.). Homepage. Retrieved November 01, 2021, from https://www.applyboard.com/careers

Baas, M. (2010). Imagined mobility: Migration and transnationalism among Indian students in Australia. Anthem Press

Barrientos, S. W. (2013). "Labour chains": Analysing the role of labour contractors in global production networks. The Journal of Development Studies, 49(8), 1058-1071. https://doi.org/10.1080/00220 388.2013.780040

Bascaramurty, D., Bhat, N., \& Rana, U. (2021, November 04). In India and Canada's international student recruiting machine, opportunity turns to grief and exploitation. The Globe and Mail. https:// www.theglobeandmail.com/canada/article-india-canada-international-student-recruitment/

Baughan, B. K., \& Minhas, J. S. (2018). Analysis of international students' struggles and challenges in British Columbia. World Sikh Organization, BC Intern. BC Government (2021). Immigration fraud and scams. https://www.welcomebc.ca/Immigrate-to-B-C/B-C-Provincial-Nominee-Progr am/Immigration-Fraud-and-Scams

BC Government (2021). Immigration fraud and scams.https://www.welcomebc.ca/Immigrate-to-B-C/BC-Provincial-Nominee-Program/Immigration-Fraud-and-Scams

Beech, S. E. (2015). International student mobility: The role of social networks. Social \& Cultural Geography, 16(3), 332-350. https://doi.org/10.1080/14649365.2014.983961

Beech, S. E. (2018). Adapting to change in the higher education system: International student mobility as a migration industry. Journal of Ethnic and Migration Studies, 44(4), 610-625. https://doi.org/ 10.1080/1369183X.2017.1315515

Birrell, B. (2005). Immigration rules and the overseas student market in Australia. IDP Education Australia Limited

Bodycott, P., \& Lai, A. (2012). The influence and implications of Chinese culture in the decision to undertake cross-border higher education. Journal of Studies in International Education, 16(3), 252-270. https://doi.org/10.1177/1028315311418517

Brooks, R. J., \& Waters, J. (2011). Student mobilities, migration and the internationalisation of higher education. Palgrave Macmillan.

Brown, P., \& Lauder, H. (2006). Globalisation, knowledge and the myth of the magnet economy. Globalisation, Societies and Education, 4(1), 25-57. https://doi.org/10.1080/14767720600555046

Brown, P., Lauder, H., \& Ashton, D. (2011). The global auction: The broken promises of education, jobs, and incomes. Oxford University Press.

Brunner, L. (2022). Towards a more just Canadian education-migration system: International student mobility in crisis. Studies in Social Justice 16 (1) https://doi.org/10.26522/ssj.v16i1.2685

Caluya, G., Probyn, E., \& Vyas, S. (2011). "Affective eduscapes": The case of Indian students within Australian international higher education. Cambridge Journal of Education, 41(1), 85-99. https:// doi.org/10.1080/0305764X.2010.549455

CBIE. (2014). Internationalization statement of principles for Canadian educational institutions. https:// cbie.ca/?s=Internationalization+statement+of ++principles+for+Canadian+educational+insti tutions.+

CBIE. (2018). International students in Canada. https://cbie.ca/wp-content/uploads/2018/09/Internatio nal-Students-in-Canada-ENG.pdf

CBIE. (2020). Infographic. https://cbie.ca/infographic

Chen, Z. J., \& Skuterud, M. (2021). Relative academic achievement of international students: Evidence from an Ontario university. UTP Journals, 46(1), 125-144. https://doi.org/10.3138/cpp.2019-033

Choi, Y., \& Hou, F., \& Chan, P. C. (2021). Early earnings trajectories of international students after graduation from postsecondary programs. Statistics Canada. https://doi.org/10.25318/3628000120 2100200004-eng

Citizenship and Immigration Canada. (2015, June). The post-graduation work permit program: Options for program redesign. Advice to Minister [internal report]

Coffey, R., \& Perry, L. M. (2013). Council of ministers of education, Canada. https://www.cmec.ca/ Publications/Lists/Publications/Attachments/326/The-Role-of-Education-Agents-EN.pdf

Collins, F. L. (2012). Organizing student mobility: Education agents and student migration to New Zealand. Pacific Affairs, 85(1), 137-160. https://doi.org/10.5509/2012851137

Connell, R. (2013). The neoliberal cascade and education: An essay on the market agenda and its consequences. Critical Studies in Education, 54(2), 99-112. https://doi.org/10.1080/17508487.2013. 776990 
Cranston, S., Schapendonk, J., \& Spaan, E. (2018). New directions in exploring the migration industries: Introduction to special issue. Journal of Ethnic and Migration Studies, 44(4), 543-557. https://doi. org/10.1080/1369183X.2017.1315504

CUPE. (2018). Federal funding for post-secondary education. https://cupe.azureedge.net/sites/cupe/ files/backgrounder_1_pse_federal_funding_2018_08_31_en.pdf

de Wit, H. (2002). Internationalization of higher education in the United States of America and Europe: A historical, comparative, and conceptual analysis. Greenwood Press.

Dahmi, S. (n.d). Victim of labour market impact assessment fraud shares how he lost nearly \$20,000 CAD to a ghost consultant. Omni. Retrieved November 30, 2021, from https://www.omnitv.ca/on/en/victim-of-labour-market-impact-assessment-fraud-shares-how-he-lost-nearly-20000-cad-to-a-ghostconsultant/

Dunstan, P. (2009). Engaging with education agents in international students support. http://isana.proce edings.com.au/docs/2009/paper_Dunstan.pdf

Etikan, I., Musa, S. A., \& Alkassim, R. S. (2016). Comparison of convenience sampling and purposive sampling. American Journal of Theoretical and Applied Statistics, 5(1), 1-4. https://doi.org/10.11648/j. ajtas.20160501.11

Frenette, M., Choi, Y., \& Doreleyers, A. (2020). International student enrolment in postsecondary education programs prior to COVID-19. Statistics Canada. https://www150.statcan.gc.ca/n1/pub/11-626-x/ 11-626-x2020003-eng.htm

Gamoran, A. (2008). Persisting social class inequality in U.S. education. In L. Weis (Ed.), The way class works: Readings on school, family and the economy (pp. 169-180). Routledge

Gomes, L., \& Murphy, J. (2003). An exploratory study of marketing international education online. The International Journal of Educational Management, 17(3), 116-125. https://doi.org/10.1108/09513 540310467787

Government of Canada (2019a). Student direct stream: About the process. https://www.canada.ca/en/immig ration-refugees-citizenship/services/study-canada/study-permit/student-direct-stream.html

Government of Canada. (2019b). Building on success: International education strategy (2019-2024). https://www.international.gc.ca/education/assets/pdfs/ies-sei/Building-on-Success-

Government of Canada. (2019c). Studying and working as an international student. https://www.canada.ca/ en/immigration-refugees-citizenship/services/study-canada/work.html

Government of Canada. (2020). Immigrate through express entry. https://www.canada.ca/en/immigrationrefugees-citizenship/services/immigrate-canada/express-entry.html

Government of Punjab. (2020). Punjab economic survey 2019-20. https://www.esopb.gov.in/static/PDF/ EconomicSurvey-2019-20.pdf

Grubb, W. N., \& Lazerson, M. (2009). The education gospel. Harvard University Press.

Hamel, J. (1992). Introduction: New theoretical and methodological issues. Current Sociology, 40(1), 1-7. https://doi.org/10.1177/001139292040001002

Harman, G. (2004). New directions in internationalizing higher education: Australia's development as an exporter of higher education services. Higher Education Policy, 17(1), 101-120. https://doi.org/10. 1057/palgrave.hep.8300044

Harvey, D. (2005). A brief history of neoliberalism. Oxford University Press.

Haynes, W. (2017). Pursuit of the red passport: Perceptions of global citizenship among low-paid global workers. Journal of Contemporary Issues in Education, 12(1), 4-18. http://ejournals.library.ualberta. ca/index.php/JCIE

Hou, F., Crossman, E., \& Picot, G. (2020d, August 18). Two-step immigration selection: Why did immigrant labour market outcomes vary by admission programs. Statistics Canada Economic Insights.

Houshmand, S., Spanierman, L. B., \& Tafarodi, R. W. (2014). Excluded and avoided: Racial microaggressions targeting Asian international students in Canada. Cultural Diversity and Ethnic Minority Psychology, 20(3), 377-388.

Hune-Brown, N. (2021, Oct). The shadowy business of international education. The Walrus. https://thewa lrus.ca/the-shadowy-business-of-international-education/

IELTS. (2019). Test taker performance 2019. https://www.ielts.org/for-researchers/test-statistics/test-takerperformance

IRCC. (2018, April 20). Profile of Canada's international student movement: From temporary to permanent residents. Pathways to Prosperity. Vancouver, BC. Retrieved from http://p2pcanada.ca/wp-content/ blogs.dir/1/files/2018/04/01-Angie-Larocque.pdf

IRCC. (2020, October 30). Government of Canada announces plan to support economic recovery through immigration. https:/www.canada.ca/en/immigration-refugees-citizenship/news/2020/10/governmentof-canada-announces-plan-to-support-economic-recovery-through-immigration.html 
IRCC. (2021, January 8). Government of Canada announces new policy to help former international students live in, work in and continue contributing to Canada. https://www.canada.ca/en/immigrationrefugees-citizenship/news/2021/01/government-of-canada-announces-new-policy-to-help-formerinternational-students-live-in-work-in-and-continue-contributing-to-canada

Kahlon, B. (2021). Report on the realities for international students. One Voice Canada. https://onevoiceca nada.org/wp-content/uploads/2021/05/The-Realities-of-International-Students-Evidenced-Chall enges_Full-Report-2.pdf

Kaufmann, V., Bergman, M., \& Joye, D. (2004). Motility: Mobility as capital. International Journal of Urban and Regional Research, 28(4), 745-756.

Kaur, R., \& Singh, K. (2018). Educational migration from Punjab: Disquieting realities and perceived hopes. Unistar Books

Keller, J. (2018, February 19). KPU has stopped accepting international applications for 2018. The Runner. https://runnermag.ca/2018/02/kpu-has-stopped-accepting-international-applications-for-2018/

Keung, N. (2018, December 8). More than 400 students in India told to retake language tests after Niagara College flags concerns. The Star. https:/www.thestar.com/news/canada/2018/12/08/400students-in-india-told-to-retake-language-tests-after-niagara-college-flags-concerns.html

Knight, J. (2003). Updating the definition of internationalization. International Higher Education, 33(Fall), 2-3. https://doi.org/10.6017/ihe.2003.33.7391

KPU. (2017a). Student satisfaction survey. https://www.kpu.ca/sites/default/files/Institutional\%20Ana lysis\%20and\%20Planning/6_Diversity.pdf

KPU. (2018, March 28). Regular meeting agenda. Board of Governors. https://your.kpu.ca/board/Board/ 2018\%20Agendas\%20and\%20Minutes/03\%20March\%2028,\%202018/Board\%20Regular\%20Mtg\% 20Pkge\%20Revised $\% 2018 \% 2003 \% 2028$.pdf

KPU. (2020a). KPU demographics. https://www.kpu.ca/sites/default/files/Institutional\%20Analysis\% 20and\%20Planning/SSS\%202019\%20KPU\%20Demographics\%20Final.pdf

KPU. (2020b). Graduation roll. https://www.kpu.ca/graduation/roll

Kvale, S. (1996). Interviews: An introduction to qualitative research interviewing. Sage

Laube, A. (2018, June 14). KPU's recent international tuition hike divides students and administrators. The Runner. https://runnermag.ca/?s=KPU's+recent+international+tuition+hike+divides+stude nts $+\% 09$

Marginson, S. (2004). National and global competition in higher education. The Australian Education Researcher, 31(2), 1-28. https://files.eric.ed.gov/fulltext/EJ689631.pdf

Marginson, S. (2009). Notes on globalization and higher education: With some reference to the case of Australia. In R. Trilokekar, G. A. Jones, \& A. Shubert (Eds.), Canada's universities go global (pp. 17-64). J. Lorimer \& Co.

Marginson, S. (2016). The worldwide trend to high participation higher education: Dynamics of social stratification in inclusive systems. Higher Education, 72, 413-434.

Marom, L. (2021). Outsiders-insiders-in between: Punjabi international students in Canada navigating identity amid intraethnic tensions. Globalisation, Societies and Education. https://doi.org/10. 1080/14767724.2021.1882291

Mazzarol, T., \& Soutar, G. (2001). The global market for higher education: Sustainable competitive strategies for the new millennium. Cheltenham, UK: Edward Elgar Publishing

Mazzarol, T., \& Geoffrey, N. S. (2002). "Push-pull" factors influencing international student destination choice. The International Journal of Educational Management, 16(2), 82-90.

Mehra, A. (2019, December 1). Why mini-Punjabs sprout in distant lands. The Hindu. https://www.thehi ndu.com/opinion/open-page/why-mini-punjabs-sprout-in-distant-lands/article30124230.ece

Naidoo, V. (2010). From ivory towers to international business: Are universities export ready in their recruitment of international students? Journal of Studies in International Education, 14(1), 5-28. https://doi.org/10.1177/1028315308327953

OECD. (2019, August 13). Recruiting immigrant workers: Canada 2019. International Migration Division. https://www.oecd.org/migration/mig/recruiting-immigrant-workers-canada-2019-4abab00den.htm

Olssen, M., \& Peters, M. A. (2005). Neoliberalism, higher education and the knowledge economy: From the free market to knowledge capitalism. Journal of Education Policy, 20(3), 313-345. https://doi. org/10.1080/02680930500108718

Pimpa, N. (2003). The influence of peers and student recruitment agencies on Thai students'choices of international education. Journal of Studies in International Education, 7(2), 178-192. https://doi. org/10.1177/1028315303007002005 
Raimo, V., Humfrey, C., \& Huang, I. Y. (2014). Managing international student recruitment agents: Approaches, benefits and challenges. https://www.britishcouncil.org/sites/default/files/managing education_agents_report_for_bc_2.pdf

Robertson, S. (2013). Transnational student-migrants and the state: The education-migration nexus. London, UK. Palgrave Macmillan

Robinson-Pant, A., \& Magyar, A. (2018). The recruitment agent in internationalized higher education: Commercial broker and cultural mediator. Journal of Studies in International Education, 22(3), 225-241. https://doi.org/10.1177/1028315318762485

Roy, V. (2019, February 23). Foreign dreams make IELTS coaching Rs 1,100-cr industry. The Tribune. https://www.tribuneindia.com/news/archive/foreign-dreams-make-ielts-coaching-rs-1-100-cr-indus try-733521

Scott, C., Safdar, S., Trilokekar, R. D., \& El Masri, A. (2015). International students as "ideal immigrants" in Canada: A disconnect between policy makers' assumptions and the lived experiences of international students. Comparative and International Education/éducation Comparée Et Internationale, 43(3), 5. https://doi.org/10.5206/cie-eci.v43i3.9261

Seidman, I. (2005). Interviewing as a qualitative research (3rd ed.). Teacher College Press

Shan, A. A., Lopes, A., \& Kareem, L. (2019). Challenges faced by international students at Kwantlen Polytechnic University". International Journal of Multidisciplinary Perspectives in Higher Education, $4(1), 111-135$.

Sheller, M. (2018). Mobility justice: The politics of movement in an age of extremes. Verso

Sheller, M. (2019). Theorizing mobility justice. In N. Cook \& D. Butz (Eds.), Mobilities, mobility justice and social justice (pp. 22-36). Routledge.

Sidhu, R. (2005). Universities and globalization: To market, to market. New York, NY. Routledge.

Statistics Canada. (2016). Census profile Surrey and BC. https://www.statcan.gc.ca/eng/start

Statistics Canada. (2020). Financial information of universities for the 2018/2019 school year and projected impact of COVID-19 for 2020/2021. https://www150.statcan.gc.ca/n1/daily-quotidien/201008/dq201 008b-eng.htm

Stein, S., \& Andreotti, V. (2016). Cash, competition, or charity: International students and the global imaginary. Higher Education, 72(2), 225-239.

Thieme, S. (2017). Educational consultants in Nepal: Professionalization of services for students who want to study abroad. Mobilities, 12(2), 243-258. https://doi.org/10.1080/17450101.2017.1292780

Thomas, S., \& Bell, A. (2008). Social class and higher education: A reorganization of opportunities. In L. Weis (Ed.), The way class works: Readings on school, family and the economy (pp. 273-287). Routledge.

Tian, J. (2017). The role of education consulting in the internationalization of higher education. Master's Thesis. UBC Open Collection. DOI 10.14288/1.0355747

Todd, D. (2019, September 3). Douglas Todd: Over-reliance on students from India and China sparks Ottawa reaction. The Vancouver Sun. https://vancouversun.com/opinion/columnists/douglas-toddfeds-to-address-over-reliance-on-students-from-india-and-china/

Tomlinson, K. (2019, April 5). False promises: Foreign workers are falling prey to a sprawling web of labour trafficking in Canada. The Globe and Mail. https://www.theglobeandmail.com/canada/articlefalse-promises-how-foreign-workers-fall-prey-to-bait-and-switch/

Tran, T., \& Thao, T. (2016). "I'm not like that, why treat me the same way?" The impact of stereotyping international students on their learning, employability, and connectedness with the workplace. The Australian Educational Researcher, 43, 203-220. https://doi.org/10.1007/s13384-015-0198-8

Trilokekar, R. D., \& El Masri, A. (2019). "International students are...golden”: Canada's changing policy contexts, approaches, and national peculiarities in attracting international students as future immigrants. In M. Kwak \& A. H. Kim (Eds.), Outward and upward mobilities: International students in Canada, their families, and structuring institutions (pp. 25-55). University of Toronto Press

Tuxen, N., \& Robertson, S. (2018). Brokering international education and (re)producing class in Mumbai. International Migration, 57(3), 280-294. https://doi.org/10.1111/imig.12516

Wadhwa, R. (2016). Students on move: Understanding decision-making process and destination choice of Indian students. Higher Education for the Future, 3(1), 54-75. https://journals.sagepub.com/ doi/https://doi.org/10.1177/2347631115610221

Weis, L., \& Dolby, N. (Eds). (2012). Social class and education: Global perspectives. New York, NY. Routledge

World Bank. (2021). Labor force with advanced education-Canada https://data.worldbank.org/indicator/SL. TLF.ADVN.ZS ?locations $=$ CA 
$\mathrm{Xu}, \mathrm{H}$. (2020). Recruitment of international students in Canadian higher education: Factors influencing students' perceptions and experiences. University of Prince Edward Island. https://islandscholar.ca/islan dora/object/ir:23288/datastream/PDF/download/citation.pdf

Yin, R. K. (2009). Case study research: Design and methods $\left(5^{\text {th }}\right.$ ed.). Thousand Oaks, CA: Sage.

Zheng, P. (2014). Antecedents to international student inflows to UK higher education: A comparative analysis. Journal of Business Research, 67(2), 136-143. https://doi.org/10.1016/j.jbusres.2012.11.003

Publisher's Note Springer Nature remains neutral with regard to jurisdictional claims in published maps and institutional affiliations. 